\title{
The effect of DNaseI enzyme on food pathogens subjected to different food processing treatments.
}

\author{
L. Mahesha N. Sigera Nadugala* and Sudip K. Rakshit \\ Food Engineering and Bioprocess Technology Programme, Asian Institute of Technology, SERD, P.O. Box 4 Klong Luang, \\ Pathumthani 12120, Bangkok, Thailand.
}

Revised: 02 April 2007 ; Accepted: 20 April 2007

\begin{abstract}
Detection of pathogens in contaminated food products by PCR can result in false-positive results due to amplification of DNA from non-viable cells. DNase treated DNA polymerase chain reaction (DTD-PCR) has been attempted to eliminate such contaminating DNAs from nonviable cells prior to the isolation of template DNA, and to improve the overall fidelity of such detection methods. The main objective of this work was to determine the effect of different DNaseI enzyme treatments on the DNA present in viable and non-viable cells that were subjected to different food processing treatments. Hypothesis was based on the use of DNasel for the differentiation of viable and non-viable cells of food borne pathogens. The effect was observed both on gram positive (Listeria monocytogenes) and gram negative cells (Escherichia coli $0157: \mathrm{H7}$ ) of food pathogens after subjecting the cells to a range of heat, cold and chemical treatments. The penetrability of DNaseI enzyme into the cells and the subsequent digestion of DNA residing in the cell are based on the type and extent of DNasel treatment and the gram character of the cells. The results indicate the possibility of using DNaseI to distinguish between viable and non-viable cells that were produced by heat treatments and some chemical treatments (ethyl alcohol and sodium hypochlorite). However, this cannot be applied for differentiation between viable and non-viable cells produced by cold treatments and sodium chloride treatments. Overall results confirmed the potential of developing DTD-PCR to differentiate the viable cells from the non-viable cells of test organisms after subjecting them to heat treatment, ethyl alcohol treatment and sodium hypochlorite treatment.
\end{abstract}

Keywords: Detection, DNaseI, food borne pathogens, $P C R$

\section{INTRODUCTION}

There is a distinct need to develop rapid detection methods for food pathogens since conventional methods are cumbersome and time consuming. The most serious limitation of using standard PCR methods lies in the fact that they fail to distinguish between live and dead cells and the resultant need for an initial enrichment step. The standard PCR methods amplify both DNA sourcing from live cells and dead cells including the free extraneous DNA already released to the media due to dead and lysed cells. DNase treated DNA polymerase chain reaction (DTD-PCR) method has been attempted to eliminate such contaminating DNA from dead cells prior to the isolation of template DNA, and to improve the overall fidelity of such detection methods ${ }^{1}$. These methods could therefore be cheaper than the more sophisticated methods like Reverse Transcriptase Polymerase Chain Reaction (RTPCR), nucleic acid sequence based amplification (NASBA), etc ${ }^{2}$. In the experiments reported in this study the cell walls of harvested bacterial cells have been exposed to crude DNaseI enzyme treatment.

Deoxyribonuclease (DNase) is a nuclease enzyme that catalyzes the hydrolytic cleavage of phosphodiester linkages in the DNA backbone. DNaseI digestion of heterogeneous double stranded DNA (dsDNA) reported always a mixture of nucleotides with yields of dinucleotides $(60 \%)$, trinucleotides $(25 \%)$, and oligonucleotides $^{3}$. The smallest substrate for DNaseI is a trinucleotide. Although DNaseI is commonly perceived to cleave DNA non specifically, in practice it does show some sequence preference. It acts on single stranded DNA, double stranded DNA, and chromatin ${ }^{4}$. Like many enzymes, DNaseI activity is also affected by the composition of the reaction buffer and is not active in buffers containing $\mathrm{Mg}^{2+}$ yet lacking $\mathrm{Ca}^{2+5}$. Since DNaseI is a powerful research tool for DNA manipulations, it is used in a range of molecular biology applications such as: degradation of contaminating DNA after RNA

\footnotetext{
"Corresponding author
} 
isolation, "clean-up" of RNA prior to RT-PCR", prevention of clumping when handling cultured cells, and creation of a fragmented library of DNA sequences for in vitro recombination reactions etc?

In this study we report the potential of DNaseI enzyme to penetrate into the cells of gram positive and negative bacteria that were subjected to different food processing and sterilization treatments. The aim was to develop an effective and low cost tool to avoid false positive results obtained in the presence of the non-viable cells by a PCR due to the presence of extraneous DNA in the sample. This was taken as a preliminary step towards the development of a PCR based method; DTD-PCR for detection of viable food borne pathogens. Activity of DNaseI on the intra and extra cellular DNA was observed by means of touchdown PCR and reconfirmed by doing a second round of touchdown PCR by taking the initial PCR product as the template in the second round.

\section{METHODS AND MATERIALS}

Bacterial strains and culturing: The selected reference organisms that belong to gram positive and gram negative groups, L. monocytogenes and E. coli $0157: \mathrm{H} 7$ respectively, were cultured on tryptic soy broth yeast extract (TSBYE) (Difco Laboratories, Detroit, MI, USA) agar medium $(1.5 \% \mathrm{w} / \mathrm{v})$ and incubated under aerobic conditions overnight at $37^{\circ} \mathrm{C}$.

Preparation of aliquots of cell suspension for treatments: The bacterial cells in the late log phase were harvested by centrifugation at $12,000 \mathrm{rpm}$ for $10 \mathrm{~min}$ and washed with PBS buffer $(0.2 \mathrm{M}$ sodium dihydrogen orthophosphate, $0.2 \mathrm{M}$ disodium hydrogen orthophosphate) followed by ultra pure water. Cell number was estimated by means of a haemocytometer after resuspending the cells in $250 \mathrm{~mL}$ of ultra pure water. Aliquots of cell suspension with a constant cell count of $5 \times 10^{7}$ cells $/ 100 \mu \mathrm{L}$ were prepared prior to treatments.

Different food processing and sterilization treatments: Prepared cell aliquots of gram positive and negative bacteria were subjected to various stress conditions, namely heat treatments $(\mathrm{H} 1-\mathrm{H} 3)$, cold treatments (C1-C3) and chemical treatments (Ch1-Ch3) as given in Table 2 and 3 . Then the cells were washed thoroughly with ultra pure water, to get rid of traces of salts and chemicals, prior to DNasel treatment (D1-D6).

DNase' treatment: A set of experiments were conducted to find out the penetrability of DNasel enzyme through cell walls of gram positive and negative bacteria and to find the optimum DNaseI concentration and treatment time combinations required for developing DTD-PCR system. The cell number was fixed to $5 \times 10^{7}$ cells $/ 100 \mu \mathrm{L}$ for all the treatments discussed below. Each treatment was replicated twice. DNasel (Sigma) (from bovine pancreas, minimum 2,000 Kunits/mg protein) obtained in lyophilized powder form was hydrated to a stock concentration of $5 \mathrm{U} / \mu \mathrm{L}$ using storage buffer $(10 \mathrm{mM}$ Tri$\mathrm{HCl}(\mathrm{pH} 7.5), 10 \mathrm{mM} \mathrm{CaCl} 210 \mathrm{mM} \mathrm{MgCl}{ }_{2}$ and $50 \%$ glycerol) and an aliquot of the DNasel stock solution was diluted to a working concentration of $1 \mathrm{U} / \mu \mathrm{L}$ using storage buffer. The stock and working DNaseI solutions were stored in $50 \mu \mathrm{L}$ aliquots at $-20^{\circ} \mathrm{C}$ until required. DNasel treatment was carried out at a final volume of $100 \mu \mathrm{L}$ which consisted of $20 \mu \mathrm{L}$ of reaction buffer 5-10 $\mu \mathrm{L}$ DNasel enzyme $(1 \mathrm{U} / \mu \mathrm{L})$ and $50 \mu \mathrm{L}$ cell aliquot and made up to $100 \mu \mathrm{L}$ with ultra pure water and incubated at $37^{\circ} \mathrm{C}$ for one hour. Mixing was carried out at 20 min intervals using a vortex system. DNA was extracted from cells after the DNaseI treatment. The DNasel activity was deactivated by boiling the reaction mixture in a constant temperature water bath for $10 \mathrm{~min}$.

DNA extract preparation: DNA extracts used as templates in PCR amplifications were prepared by Triton X-100 method. Bacterial DNA extracts were prepared according to the manufacturer's instructions (Easy DNA kit, Invitrogen Co., San Diego, USA). The final DNA extract was dissolved in $50 \mu \mathrm{L}$ of ultra pure nuclease free water $\left(\right.$ Seromed $\left.^{58}\right)$.

Touchdown PCR: Touchdown PCR was carried out with the DNA samples extracted from the cells that were subjected to DNasel treatment using a primer pair specific to $\mathrm{V} 3$ region of $16 \mathrm{~S}$ rDNA. In order to make the PCR efficiency independent of primer type, this universal primer pair with a product size of 193 bp was used in PCR amplification. This was done in order to check the effectiveness of DNaseI treatment. The nucleotide sequences of the primers are as follows: forward primer (V3f): 5'-CCT ACG GGA GGCAGC AG-3'; Reverse Primer (V3r) 5'-ATT ACC GCG GCT GCT GG- 3'8. Primers were prepared by Bio-service Unit of BIOTEC, Thailand and hydrated to a stock concentration of 100 pmole $/ \mu \mathrm{L}$ using sterile TE buffer (10 mM Tris-HCl, 1 mM EDTA). An aliquot of the primer stock solution was diluted to a working concentration of $50 \mathrm{pmole} / \mu \mathrm{L}$ using sterile TE buffer. The stock and working primer solutions were stored in $50 \mu \mathrm{L}$ aliquots at $-20^{\circ} \mathrm{C}$ until required. Touchdown PCR was performed in $50 \mu \mathrm{L}$ reactions in $0.2 \mathrm{~mL}$ thin walled PCR tubes. The reaction mixtures contained $25 \mu \mathrm{L}$ of Hotstar Taq master mixture (1.25 U Taq DNA polymerase, $1.5 \mathrm{mM}$ $\mathrm{MgCl}_{2}, 10$ X PCR buffer, dNTPs $200 \mu \mathrm{M}$ each), $0.25 \mu \mathrm{L}$ of each forward and reverse primers $(12.5$ pmole each $/ 50 \mu \mathrm{L})$, $1 \mu \mathrm{L}$ of template DNA and ultra pure water to bring the 
final volume to $50 \mu \mathrm{L}$. The touchdown PCR procedure was performed in a PCR Thermocycler (Biometra ${ }^{\text {TM }}$ Personel). Thermal cycling conditions for touchdown PCR are given in Table 1. The PCR amplification products were visualized in 2\% agarose gels (Analytical grade, Promega) stained with ethidium bromide $(0.2 \mu \mathrm{g} / \mathrm{mL})$ using a UV

Table 1: Thermal cycling conditions for touchdown PCR amplification.

\begin{tabular}{llclcl}
\hline Step & Temperature $\left({ }^{\circ} \mathrm{C}\right)$ & Time duration & Step & Temperature $\left({ }^{\circ} \mathrm{C}\right)$ & Time duration \\
\hline 1 & 94 & $5 \mathrm{~min}$ & 20 & 60 & $1 \mathrm{~min}$ \\
2 & 65 & $1 \mathrm{~min}$ & 21 & 72 & $3 \mathrm{~min}$ \\
3 & 72 & $3 \mathrm{~min}$ & 22 & 94 & $30 \mathrm{~s}$ \\
4 & 94 & $30 \mathrm{~s}$ & 23 & 59 & $1 \mathrm{~min}$ \\
5 & 65 & $1 \mathrm{~min}$ & 24 & 72 & $3 \mathrm{~min}$ \\
6 & 72 & $3 \mathrm{~min}$ & 25 & 94 & $30 \mathrm{~s}$ \\
7 & 94 & $30 \mathrm{~s}$ & 26 & 58 & $1 \mathrm{~min}$ \\
8 & 64 & $1 \mathrm{~min}$ & 27 & 72 & $3 \mathrm{~min}$ \\
9 & 72 & $3 \mathrm{~min}$ & 28 & 94 & $30 \mathrm{~s}$ \\
10 & 94 & $30 \mathrm{~s}$ & 29 & 57 & $3 \mathrm{~min}$ \\
11 & 63 & $1 \mathrm{~min}$ & 30 & 72 & $30 \mathrm{~s}$ \\
12 & 72 & $3 \mathrm{~min}$ & 31 & 94 & $1 \mathrm{~min}$ \\
13 & 94 & $30 \mathrm{~s}$ & 32 & 56 & $3 \mathrm{~min}$ \\
14 & 62 & $1 \mathrm{~min}$ & 33 & 72 & $30 \mathrm{~s}$ \\
15 & 72 & $3 \mathrm{~min}$ & 34 & 94 & $1 \mathrm{~min}$ \\
16 & 94 & $30 \mathrm{~s}$ & 35 & 55 & $3 \mathrm{~min}$ \\
17 & 61 & $1 \mathrm{~min}$ & 36 & 72 & $10 \mathrm{~min}$ \\
18 & 72 & $3 \mathrm{~min}$ & 37 & 72 & indefinite \\
19 & 94 & $30 \mathrm{~s}$ & 38 & 4 &
\end{tabular}

Table 2: Effect of DNasel treatment on L. monocytogenes cells that were subjected to different food processing treatments.

\begin{tabular}{|c|c|c|c|c|c|c|c|}
\hline \multirow[t]{6}{*}{ Treatments } & \multirow{2}{*}{\multicolumn{6}{|c|}{$\begin{array}{c}\text { Presence of PCR product after DNaseI } \\
\text { Treatment } \\
\text { DNasel Treatment }\end{array}$}} & \multirow{6}{*}{$\begin{array}{c}\text { Growth on TSBYE } \\
\text { broth ( } 24 \mathrm{~h} \text { incubation) }\end{array}$} \\
\hline & & & & & & & \\
\hline & \multirow{3}{*}{\multicolumn{3}{|c|}{$\begin{array}{l}\text { D1 } \quad \text { D2 } \quad \text { D3 } \\
5 \mathrm{U} / 100 \mu \mathrm{L} \\
\text { Treatment time (min) }\end{array}$}} & \multirow{3}{*}{\multicolumn{3}{|c|}{$\begin{array}{c}\text { D4 D5 D6 } \\
10 \mathrm{U} / 100 \mu \mathrm{L} \\
\text { Treatment time (min) }\end{array}$}} & \\
\hline & & & & & & & \\
\hline & & & & & & & \\
\hline & 20 & 40 & 60 & 20 & 40 & 60 & \\
\hline Control & $\sqrt{ }$ & $\checkmark$ & $\sqrt{ }$ & $\sqrt{ }$ & $\sqrt{ }$ & $\sqrt{ }$ & $\sqrt{ }$ \\
\hline \multicolumn{8}{|l|}{ Heat treatments } \\
\hline $\mathrm{H} 1: 90^{\circ} \mathrm{C}, 10 \mathrm{~min}$ & $\sqrt{ }$ & $\sqrt{ }$ & $\sqrt{ }$ & $\mathrm{X}$ & $\mathrm{x}$ & $\mathbf{x}$ & $\mathrm{x}$ \\
\hline $\mathrm{H} 2: 100^{\circ} \mathrm{C}, 10 \mathrm{~min}$ & $\mathrm{x}$ & $\mathrm{X}$ & $\mathrm{x}$ & $\mathbf{X}$ & $\mathrm{x}$ & $\mathrm{x}$ & $\mathrm{X}$ \\
\hline H3: $121^{\circ} \mathrm{C}, 15 \mathrm{~min}$.pressure $120 \mathrm{kgf} / \mathrm{cm}^{2}$ & $\mathrm{x}$ & $\mathrm{X}$ & $\mathrm{X}$ & $\mathbf{X}$ & $\mathrm{X}$ & $\mathrm{X}$ & $\mathrm{X}$ \\
\hline \multicolumn{8}{|l|}{ Cold treatments } \\
\hline $\mathrm{C} 1: 0^{\circ} \mathrm{C}, 24$ hours & $\mathbf{x}$ & $\mathbf{x}$ & $\mathrm{X}$ & $\mathrm{X}$ & $\mathrm{x}$ & $\mathrm{x}$ & $\checkmark$ \\
\hline $\mathrm{C} 2:-10^{\circ} \mathrm{C}, 24$ hours & $\mathrm{x}$ & $\mathrm{X}$ & $\mathrm{x}$ & $\mathbf{X}$ & $\mathrm{x}$ & $\mathrm{X}$ & $\sqrt{ }$ \\
\hline $\mathrm{C} 3:-20^{\circ} \mathrm{C}, 24$ hours & $\mathrm{x}$ & $\mathrm{X}$ & $\mathrm{x}$ & $\mathbf{X}$ & $\mathrm{x}$ & $\mathrm{X}$ & $\sqrt{ }$ \\
\hline \multicolumn{8}{|l|}{ Chemical treatments } \\
\hline Ch1: Ethyl alcohol $(80 \%), 30 \mathrm{~min}$ & $\mathbf{x}$ & $\mathrm{x}$ & $\mathrm{x}$ & $\mathrm{X}$ & $\mathbf{x}$ & $\mathbf{X}$ & $\mathrm{X}$ \\
\hline Ch2: Sodium hypochlorite $(0.1 \%), 30 \mathrm{~min}$ & $\mathbf{x}$ & $\mathbf{X}$ & $\mathrm{x}$ & $\mathrm{X}$ & $\mathrm{X}$ & $\mathrm{X}$ & $\mathbf{X}$ \\
\hline Ch3: Sodium chloride $(10 \%), 30 \mathrm{~min}$ & $\checkmark$ & $\sqrt{ }$ & $\sqrt{ }$ & $\checkmark$ & $\checkmark$ & $\sqrt{ }$ & $\sqrt{ }$ \\
\hline
\end{tabular}

-presence of PCR products, X-absence of PCR products.

Control: without heat, cold or chemical treatments. 
Table 3: Effect of DNasel treatment on E. coli cells that were subjected to different food processing treatments.

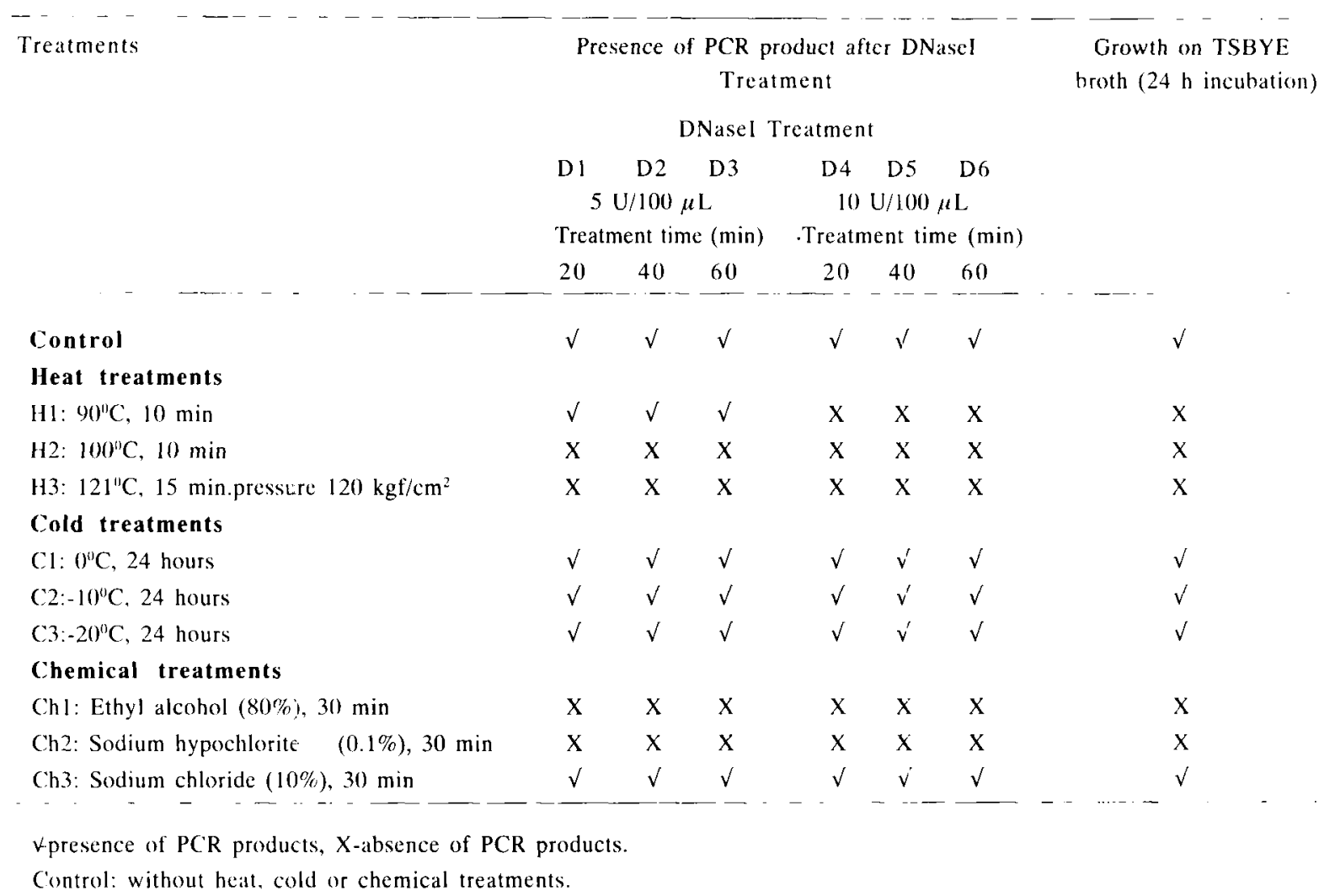

transilluminator. Touchdown PCR results were reconfirmed by a second round of touchdown PCR process by taking the amplicons of first PCR assay as the template.

\section{DISCUSSION AND CONCLUSION}

\section{Effect of heat treatments}

Growth was not observed in both bacteria Listeria monocytogenes and Escherichia coli $0157: \mathrm{H} 7$ after being subjected to three different heat treatments $(\mathrm{H} 1, \mathrm{H} 2, \mathrm{H} 3)$. This confirmed that the heat treatments were powerful enough to kill the cells. The DNasel treatments were found effective enough to digest all DNA present in cells subjected to $\mathrm{H} 2$ and $\mathrm{H} 3$ treatments at both concentrations of $5 \mathrm{U} / 100 \mu \mathrm{L}$ and $10 \mathrm{U} / 100 \mu \mathrm{L}$ in both species of bacterial cells. However the DNasel treatment of cells subjected to H] treatment (for $20,40,60 \mathrm{~min}$ ) at a concentration of $5 \mathrm{U}$ / $100 \mu \mathrm{L}$ was not effective. The cells treated at this temperature produce PCR bands with very low intensity even after the DNasel treatment with a concentration of $5 \mathrm{U} / 100 \mu \mathrm{L}$ for all treatment times tested (Figure 1). However, the cells subjected to $\mathrm{H} 1$ treatment did not yield any PCR product when treated with enzyme at a concentration of $10 \mathrm{U} / 100 \mu \mathrm{L}$ which showed the insufficiency of DNasel concentration in earlier treatment.
This result was common to both $L$. monocytogenes and E. coli $\mathrm{O} 157: \mathrm{H} 7$ cells. The results obtained indicate that the heat treatments given are capable of killing cells of both bacteria tested and $10 \mathrm{U}_{1}^{\prime} 100 \mu \mathrm{L}$ DNasel treatment for 20-60 min of incubation time is effective to remove all DNA residing in the cells of both bacteria tested.

\section{Effect of cold treatments}

In cold treatments tested, the DNase I treatments $(5 \mathrm{U} / 100$ $\mu \mathrm{L}$ and $10 \mathrm{U} / 100 \mu \mathrm{L}$ at all treatment times tested) were effective enough to digest all the DNA present in cells of L. monocytogenes (gel picture not given). But the cells showed normal growth after undergoing $\mathrm{C} 1, \mathrm{C} 2$ and $\mathrm{C} 3$ treatments, which proved their ability to grow after a freeze shock. The absence of PCF products indicates the possibility of penetration of the DNasel enzyme across the cell membrane of cold treated cells of

\section{L. monocytogenes.}

In the case of $E$. coli $0157: \mathrm{H} 7$ cells (Figure 2) the results were totally different. The cells subjected to the three cold treatments produced PCR products after the DNaseI treatment which confirmed that the different cold shocks given are insufficient to make cell wall changes or make it permeable for DNaseI in gram negative bacteria that have two layers of plasma membranes. Literature 


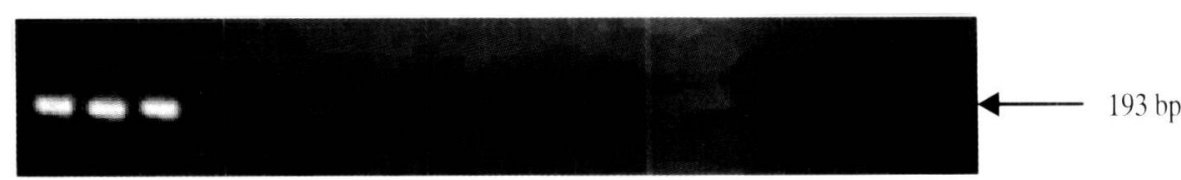

Figure 1: PCR products of heat treated cells of E. coli O157:H7 after DNasel treatment.

(Note: Identical PCR band pattern was observed when L. monocytogenes heat treated cells were subjected to the same DNaseI treatments).

lane 1, Treatments H1, D1;

lane 2, Treatments H1, D2;

lane 3, Treatments H1, D3;

lane 4, Treatments H1, D4;

lane 5, Treatments H1, D5;

lane 6, Treatments H1, D6;

lane 7, Treatments H2, D1;

lane 8 , Treatments $\mathrm{H} 2, \mathrm{D} 2$;

lane 9 , Treatments H2, D3; lane 10, Treatments H2, D4;

lane 11, Treatments H2, D5;

lane 12, Treatments H2, D6;

lane 13, Treatments H3, D1;

lane 14, Treatments H3, D2;

lane 15, Treatments H3, D3;

lane 16, Treatments H3, D4;

lane 17, Treatments H3, D5;

lane 18 , Treatments H3, D6

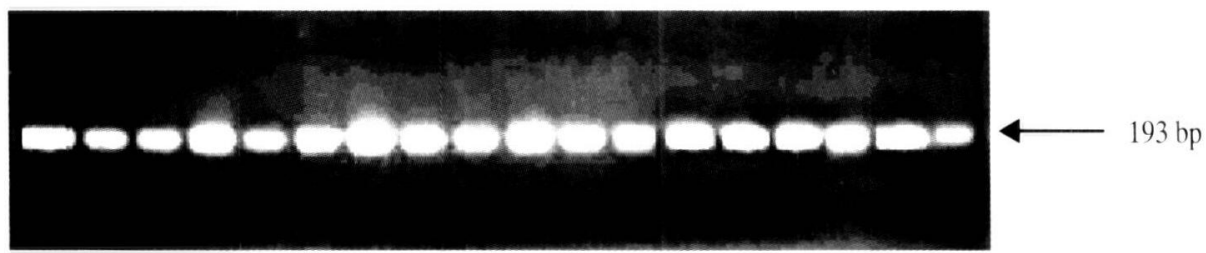

Figure 2: PCR products of cold treated cells of $E$. coli $\mathrm{O} 157: \mathrm{H} 7$ after DNasel treatment.

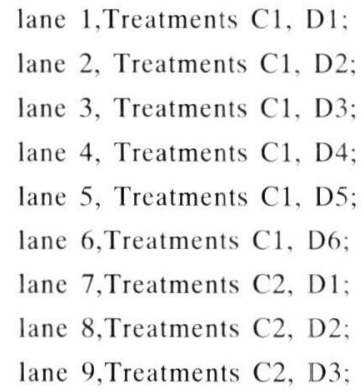

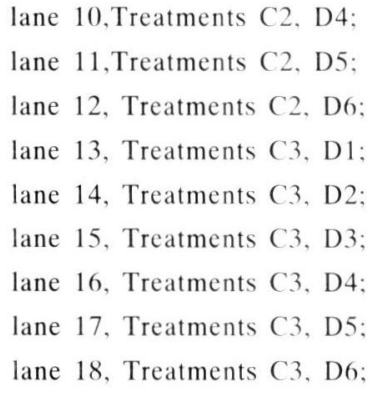

indicates that both gram positive and gram negative bacteria have been shown to be affected by cold shock ${ }^{9}$. During rapid cooling, permeability changes in the cell membrane are caused by a phase transition in the cell membrane lipids from liquid crystalline to a gel state? Slow cooling allows lateral phase separation of the lipids and proteins of the membrane, whereas rapid cooling "fixes" these components in a random, disordered state, resulting membrane leakiness ${ }^{10}$. The results of this experiment with cold treatment indicate that the given treatments are capable of making permeability changes in the cell wall of L. monocytogenes but not in E. coli O157:H7. The results also confirmed that the cold treatments tested were not powerful enough to kill the cells of both bacteria.

\section{Effect of chemical treatments}

In different chemical treatments (Figure 3 ), the ceils ( $L$. monocytogenes and $E$. coli $\mathrm{O} 157: \mathrm{H} 7)$ that were subjectedo 


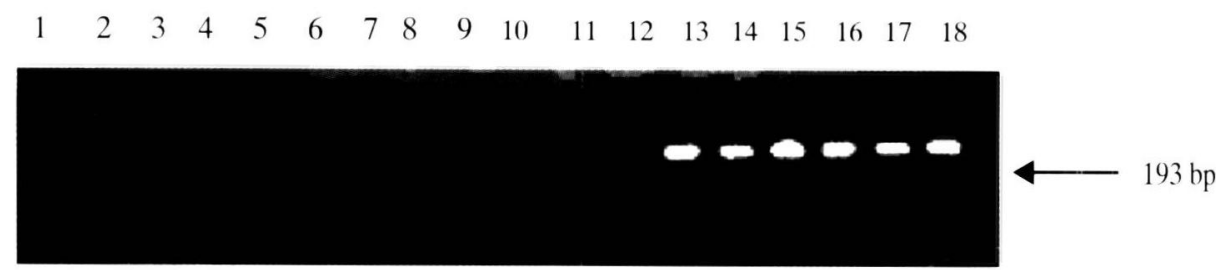

Figure 3: PCR products of chemically treated cells of E. coli O157:H7 after DNasel treatment

(Note: Identical PCR band pattern was observed when L. monocytogenes chemically treated cells were subjected to the same DNaseI treatments).

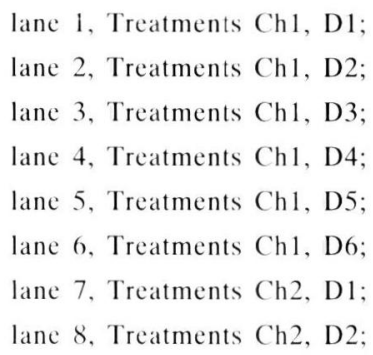

Ch3 treatment grew in TSBYE and also yielded PCR products at different DNasel treatments in both bacteria. It has been reported that $L$. monocytogenes can survive under a variety of environmental stresses, such as $10 \%$ $\mathrm{NaCl}$ solutions ${ }^{11}$. This bacterium can also be detected after 150 days in pure salt at $22^{\prime \prime} \mathrm{C}^{12}$. E. coli $\mathrm{O} 157: \mathrm{H} 7$ can survive in $10 \% \mathrm{NaCl}$ solutions $\mathrm{s}^{13}$. The presence of PCR products can be due to two reasons. Firstly, the main physiological change that occurs due to salt treatment is plasmolysis, which causes cell membrane shrinkage but slight or no changes in the cell wall structure, especially permeability. Therefore, DNasel movement is not facilitated by these treatments. Secondly, as the literature says, DNaseI is very sensitive to different salts present in reaction buffer ${ }^{5}$. In $\mathrm{Ch} 3$ treatment there are chances for traces of $\mathrm{NaCl}$ that may remain after the washing step which could subsequently inhibit the DNaseI activity. This is a practical error which was kept at minimum level by washing the cells thoroughly with ultra pure water several times to get rid of traces of salts and chemicals prior to DNaseI treatment. Therefore, it was assumed that there were no traces of salts that could interrupt the activity of DNaseI.

In Ch1 and Ch2 treatments cells (L. monocytogenes and E. coli $\mathrm{O} 157: \mathrm{H} 7$ ) were killed after treatments and PCR products were not produced in any of the DNaseI treatments that were tested. Alcohol induced coagulation of proteins occurs at the cell wall, the cytoplasmic membrane and among the various plasma proteins ${ }^{14}$. Alcohols target the bacterial cell wall, with resultant lysis of the cytoplasmic membrane and release of cellular contents. Subsequently, this facilitates movement of DNasel into the cells and digestion of DNA. Protein coagulation occurs within concentration limits around an optimum alcohol level. In the absence of water, proteins are not denatured as readily as when water is present. Therefore, mixtures of alcohol with water exhibit much better efficacy than straight alcohol alone ${ }^{14}$.

Sodium hypochlorite forms hypochlorous acid in solution. The mechanism in which hypochlorous acid destroys microorganisms has never been demonstrated experimentally, but it has been speculated ${ }^{14}$ that hypochlorous acid allows oxygen to emerge, which in turn supposedly combines with components of cell protoplasm, destroying the organism. The results of the experiment indicates that this could facilitate the movement of DNaseI and digestion of DNA.

The overall results show that DNaseI can effectively penetrate the walls of gram positive and gram negative bacterial cells that are subjected to different heat treatments. In the case of cold treatment, the cell walls seem to become permeable for DNaseI after the treatment only in gram positive bacteria. In gram negative bacteria this is different and the cells produce expected PCR products even after giving DNasel treatment for one hour. This indicates that the cold treatments given are not sufficient to make permeability changes in cell walls of gram negative bacteria. In chemical treatments, Ch3 treatment was not able to make any permeability change in cells; hence all the cells subjected to salt treatments produced expected PCR products. But when the cells were subjected to Ch1 and Ch2 treatments the cells did not yield any PCR products. This concludes that selected Ch1 and Ch2 treatments are able to make permeability 
changes in the cell walls of gram positive and negative bacteria which facilitate the movement of DNaseI and do DNA digestion. The results indicate that DNaseI treatment could be used to destroy DNA in non-viable cells after different heat (H1-H3) treatments and some chemical (Ch1 and $\mathrm{Ch} 2$ ) treatments and this could be used as a tool to differentiate viable and non-viable cells.

\section{Acknowledgement}

We are grateful to the Armed Forces Research Institute of Medical Sciences, Department of Medical Sciences (Thailand), the Korean collection for type cultures, the Burapha University (Thailand) culture collection and the Mahidol University (Thailand) culture collection for providing the bacterial strains employed in this study.

\section{References}

1. Mukhopadhyay U.K. \& Mukhopadhyay A. (2002). A low cost, rapid, sensitive and reliable PCR - based alternative method for predicting the presence of possible live microbial contaminants in food. Current science 83: 53-56.

2. McKillip J., Jaykus L. \& Drake M. (1999). Nucleic acid persistence in heat-killed Escherichia coli $0157: \mathrm{H} 7$ from contaminated skim milk. Journal of Food Protection 62 (8):839-844.

3. Vanecko S. \& Laskowski M. (1961). Studies of the specificity of Deoxyribonuclease I.III. Hydrolysis of chains carrying a monoesterified phosphate on carbon 5'. Journal of Biological Chemistry 236: 3312-3316

4. Sutton D.H., Conn G.L., Brown T. \& Lane A.N. (1997). The dependence of DNaseI activity on the confirmation of oligonucleotides. Biochemical Journal 321:481-486.

5. Moore S. (1981). Pancreatic DNase. In: The enzymes $($ Ed. P.D.Boyer) Volume 14 A Chapter 15, pp. 281, Academic press, New York.
6. Kienzle N., Young D., Zehntner S.P., Bushell G.R. \& Scully T. (1996). DNaseI treatment is a prerequisite for the amplification of cDNA from episomal-based genes. BioTechniques 20: 612-616.

7. Ambion's TechNotes Newsletter 8:4. (2001). Ambion's Tips From the Bench DNase I Demystified. Ambion's RNA Company [Online]. http:// www.ambion.com/techlib/tips/ dnaseldemystified.html. Accessed 02.11.2004.

8. Muyzer G., De Waal E.C. \& Uitterlinden A.G. (1993). Profiling of complex microbial populations by denaturing gradient gel electrophopresis anlysis of polymerase chain reaction-amplified genes coding for 16S rRNA. Applied and Environmental Microbiology 59 (3):695-700.

9. MacLeod R.A. \& Calcott P.H. (1976). Cold shock and freezing damage to microbes. In: The Survival of Vegetative Microbes.(Eds. T.R.G. Gray and J.R. Postgate) pp.81-109, Twenty-sixth symposium of the society for general microbiology. Cambridge University press, Uk.

10. Mackey B.M. (1984). Lethal and sublethal effects of refrigeration, freezing and freeze-drying on microorganisms. In: The Revival of Injured Microbes (Eds. M.H.E. Andrew and A.D. Russell) pp. 45-75, Academic Press, Orlando, Florida.

11. McClure P.J., Roberts T.A. \& Oguru P.O. (1989). Comparison of the effects of sodium chloride, $\mathrm{pH}$ and temperature on the growth of Listeria monocytogenes on gradient plates and liquid medium. Letters in Applied Micobiology 9: 95-99.

12. Gnanou Besse N., Dubois Brissonnet F., Lafarge V. \& Leclerc V. (2000). Effect of various environmental parameters on the recovery of sublethally salt-damaged and acid-damaged Listeria monocytogenes. Journal of Applied Microbialogy 89:944 -950.

13. Chen W., Martinez G., \& Mulchandani A. (2000). Molecular beacons: a real-time polymerase chain reaction assay for detecting Salmonella. Anal Biochemistry 280:166-172.

14. Buck K.M. (2001). The Effects of Germicides on Microorganisms. Infection Control Today - 09-2001 [Online].http:// www.infectioncontroltoday.com/enews.html Accessed 11.11.2004. 